\title{
Устойчивые сравнения с персонажами Библии в языках бывшей Югославии*
}

\begin{abstract}
И. В. КУЗНЕЦОВА
Кафедра педагогики и методики начального образования, Чувашский государственный педагогический университет им. И. Я. Яковлева, ул. К. Маркса, д. 38, RU-428000 Чебоксары E-mail: irinak47@yandex.ru
\end{abstract}

(Received: 25 February 2017; accepted: 5 May 2017)

\begin{abstract}
This paper deals with the presentation of Serbian and Croatian biblical similes in dictionaries and their usage by native speakers. The author also draws material from Macedonian and Montenegrin. Some of the examples are presented with etymological commentaries.

Keywords: phraseology, similes, biblical characters, Serbian, Croatian, phraseography
\end{abstract}

«Из блока интернациональных фразеологизмов библеизмы исследованы более других единиц - и в разных аспектах: с точки зрения привязки к исходным текстам Писания, процессов исторического формирования их современных значений и выражаемых ими смыслов в сегодняшнем художественном и публицистическом контексте» (СЕливерстовА 2013: 288). Действительно, многие речения Книги книг, ставшие принадлежностью фразеологии народов, исповедующих христианство, являются интернационализмами. Среди них немало единиц с компаративной структурой. Сравнение в языке может быть выражено морфологической и синтаксической конструкцией, причем способы выражения компаративности разнообразны. Обратимся к фразеобиблеизмам бывшей Югославии союзного типа с компонентом-персонажем Священного Писания в составе сравнения.

К интернационализмам относятся такие фразеобиблеизмы, как макед. стар како Метузалем ${ }^{1}$ (FINK 2006: 239), серб. стар као Метузалем (Вуловић 2014: 47), слвн. star kot Metúzalem (WDPh 2004: 90), хорв. [biti] star kao (ko)

* Работа выполнена при финансовой поддержке проекта «Полиэтническая образовательная среда современного вуза: проблемы многоязычия и межкультурной коммуникации» (базовая часть государственного задания Министерства образования и науки Российской Федерации в 2017 г. (№ 27.9712.2017/БЧ).

${ }^{1}$ Рус. стар (старый) как Мафусаил (БЕТеХтинА 1999: 166, SČFI 1983: 205); укр. старий як Марусаӥл (НУФС 1: 27); болг. стар като Матусал (НБФР 1: 56, НБФР 2: 37); в.-луж. stary kaž Metusala (RADYSERB-WJELA 1902: 19); слвц. starý ako Matuzalem (SMIEŠKovÁ 1974: 133); чеш. [být] starý jako Methusalem (Metuzalém) (ZAORÁLEK 2000: 485, SČFI 1983: 31, 204); кашуб. stôri jak Matuzalem; stôri jak Matuzalem, co żyt prawie tësquc lat (TREDER 1989: 137); венг. vén, mint Matuzsálem (O. NAGY 1976: 469); англ. [as] old as Methuselah (БЕтеХтинА 1999: 170, SČFI 1983: 31); нем. [so] alt wie Methusalem [sein] (WW 1982: 57, WDPh 2004: 90); голл. zо оиd as Methusalem (WALTER 2008: 204); фp. vieux comme Mathusalem (SČFI 1983: 31). 
Metuzalem (RAguž 1979: 22, cp. MenaC-Mihalić 2003-2004: 371); серб. мудар (паметан) као Соломон (Вуловић 2014: 46), хорв. тиdar kao Salomon (Solomun, Solomon $)^{2}$ (ОРАšÍ́ 2014: 191); серб. умити (прати /опрати) руке као Пилат (Вуловит 2014: 48), слвн. opráti si (umíti si) rôke [kot Pilát], ${ }^{3}$ хорв. umite (pratiloprati) ruke [kao Pilat] $]^{4}$ (МАтЕŠIĆ 1982: 588); серб. досnети [попасть] као Пилат у «Вјерују» ${ }^{5}$ (Вероваье), наћи се [оказаться] као Пилат у Вјерују (Веровању), упасти [влезть] као Пилат у Вјерују (Вуловић 2014: 48, КончАРевит 2015: 152), слвн. kàkor (kot) Pilát v krédo (crédo), ${ }^{6}$ хорв. dospjeti (upasti) [u što] kao Pilat u Vjerovanje (u Kredo), upadnuti u nešto kao Pilat u Vjerovanje ${ }^{7}$ (Ribarova 2001: 74), naći kao Pilat u Vjerovanju (u Kredu) ${ }^{8}$ (MAtešı́c 1982: 467,

${ }^{2}$ Рус. мудрый (умный) как (словно, точно) [иарь] Соломон (БМС 1997: 321, ОГОльцЕВ 1994: 388); бел. разумный нібы Саламон (FEDEROWSKI 1935: 170); укр. мудрий як Соломон (Саламон, Салимон); як мудрий Салимон; премудрий як Саламон (ФРАнКо 1907: 415, 588, ЮрчЕНКО-ІВченКО 1993: 130); лемк. мудрый як Соломон (Шаламун, Саламун краль) (ВАРХОЛІвченКо 1990: 126, 118, 145); болг. мъдър като Соломон (КювлиЕВА-МишАЙКОВА 1986: 162); слвц. múdry ako Šalamún (SMIEŠKOVÁ 1974: 244, KSSJ 2003: 733); чеш. je moudrý (chytrý) jak (jako) Šalomoun (Šalamoun) (ZAORÁLEK 2000: 535, SČFI 1983: 345, MoKIENKO-WuRM 2002: 515); польск. madry jak Salomon (SKORUPKA 1: 430); кашуб. mqdri jak [król] Salamon (TREDER 1989: 137); англ. be as wise as Salomon (Кунин 1984: 1030); нем. weise wie Salomo (BüсHмANN 1864: 145, WALTER 2008: 249); фp. être sage comme Salomon (SČFI 1983: 345); венг. bölcs, mint Salamon [király] (Vöö 1999: 46).

${ }^{3} \mathrm{http}: / /$ www.fran.si/192/janez-keber-frazeoloski-slovar-slovenskega-jezika/4215398

${ }^{4}$ Рус. умылть/умылвать [свои] руки [как Пилат] (Михельсон 2: 418, SČFI 1983: 270, ССРЯ 2003: 318); болг. измивам си ръиете като Пилат (Вуловић 2014: 217, сн. 229); измивам ръиете си от вина [като Пилат] (НБФР 2: 701); в.-луж. sej ruce тус́/ wuтус́ [kaž Pilatus] (IvČENKO-WÖLKe 2004: 298); слвц. umývat' si/umyt' si ruky [ako Pilát] (SMIEŠKOVÁ 1974: 257, SKLadanÁ 1993: 133); чеш. mýt si ruce jako [Pontský] Pilát (Pilát Pontský) (SČFI 1983: 270, ГPEHAPOBA 2006: 736); mýt si ruce nad čím jak Pontský Pilát; mýt (umýt) si ruce jako Pilát [Pontský] (PAVlasovÁ 2013: 60); umyl si ruky ako Pilát (ZÁTURECKÝ 2005: 210); польск. umywać / umyć ręce [jak Piłat] (ПРФС 2: 309, SKORUPКA 1: 679).

${ }^{5}$ Bjepyjy («Верую») - народное название молитвы «Символ Веры» = «Apostolsko vjerovanje» (от слова, которым она начинается: Верую во единаго Бога Отца, Вседержителя...).

${ }_{7}^{6} \mathrm{http}: / / w w w . f r a n . s i / 192 / j a n e z-k e b e r-f r a z e o l o s k i-s l o v a r-s l o v e n s k e g a-j e z i k a / 4215398$

${ }^{7}$ «Eto tako je završila bajka, u koju sam upao kao Pilat u Vjerovanje ter sam nevoljko krenuo na put» (hrWaC).

${ }^{8}$ Чеш. dostat se (přijit) do něčeho jako Pilát do kréda; príijit k čemu jak(o) Pilát do kréda; přišel k tomu jako Pilát do kréda; dostal se do toho jako Pilát do kreda (do Věrím); dostal se do toho jako Pilát do Kreda; patřit kam jako (Pontský) Pilát do kréda; patřit někam jako v krédo Pontský Pilát (Pavlasová 2013: 117); dostal se do toho (prijít do čeho) jako Pilát do Kréda (kréda, Věrím) (ZAORÁleK 2000: 508, 626, SČFI 1983: 33, PAVLASOVÁ 2013: 117); слвц. dostat' sa niekam, do niečoho ako Pilát do kréda (SMIEŠKOVÁ 1974: 113); польск. dostać się jak Piłat w Credo (kredo) (SKORUPKA 1: 679, KSJP 1998); włazł (wmieszat się) jak Piłat w credo (kredo, w credzie) (NKP 2: 930, KSJP 1998); кашуб. wmieszac sęjak Piłôt w Kredo (RAмUŁт 1893: 134, 255); венг. belekerült (úgy került bele), mint Pilátus a krédóba (O. NAGY 1976: 558); нем. hineingeraten wie Pilatus ins Credo (НБФР 2: 152); er ist dazu gekommen wie Pilatus ins Credo; wie der Pontius ins Credo kommen (WALTER 2008: 232-233) - 'попасть куда-л., очутиться где-л. случайно, без собственных усилий, не по своим заслугам или не по своей вине; получить что-л. нежданно-негаданно'. Эти фразеологизмы обязаны своим происхождением не тексту Библии, а связаны со случайностью упоминания имени римского прокуратора в этой молитве. 
RIBAROVA 2001: 72); макед. очекува (чека) некого како Бога ${ }^{9}$ (FINK 2006: 238); хорв. očekuvati/čekati kao Mesiju $\operatorname{koga}^{10}$ (FINK 2006: 238); черногор. pacneme га ка Жуђели [евреи] Христа ${ }^{11}$ (РАдОВИЋ 1962: № 4666); хорв. strpjiv (strpljiv) kao (ko) Job ${ }^{12}$ (RAguž 1979: 21, cp. MenaC-MenaC-Mihalić 1998: 305, MenaCMiHALIĆ 2003-2004: 366); ležati [bespomoćno] kao Lazar (RIBAROVA 2001: 72), biti (ležati) kao Lazar ${ }^{13}$ (OPAŠıć 2014: 194); strpljivi kao biblijski Job; ${ }^{14}$ star kao

${ }^{9}$ Рус. ждать как Бога (Огольцев 2001: 62); укр. ждати як Бога (Номис 1993: 356); жде як [пана] бога 'ждать с нетерпением' (Юрченко-Івченко 1993: 16); бел. чакаць (ждаць) як бога 'очень ждать с надеждой на что-то хорошее' (ЛЕПЕшАў 1: 108, ФядосІк 1979: 319).

${ }^{10}$ Рус. ждать кого как [евреи] Мессию; ожидать чего как [евреи] Мессию (прихода Мессии) (НКРЯ); укр. чекати (ждати) як Месію (Месії) кого; болг. очаквам/чакам като Мессия някого; польск. czekać jak na Mesjasza na kogoś (FINK 2006: 238); czeka jak Żydzi Mesjasza (NKP 3: 979); слвц. čaka ho ako Żidia Mesiàša (ZÁTURECKÝ 2005: 375, FS 1996: 104); očakávat' ako Mesiáša (SNK); čakat ako Mesiáša (na Mesiáša) koho (FINK 2006: 238); венг. vár vkit, mint a Messiást (информант - Й. А. Балажи). Сравнение связано с предсказаниями евангелистов о втором (новом) пришествии Христа на землю перед концом света.

${ }^{11}$ Рус. распять кого как [Иисуса] Христа может иметь в текстах разное значение. Прямое значение 'пригвоздить к чему-л.; насильственно развести чьи-нибудь руки в разные стороны' реализуется в строках: «-Кто распял-то? - Жиды распяли, как Христа» (П. Н. Краснов: От Двуглавого Орла к красному знамени, 1922); «Блатные распяли меня, как Иисуса Христа, на крестовине нар и заново разломали руку, обе кости (фраер не имеет права бить вора)» (Г. Жженов: Прожитое, 2002); семантика 'предать каре, духовному наказанию' - в текстах: «С попами, с чудотворными иконами, с мощами - a... Распинает, как Христа! Понимаете, товарищ, силу сей аллегории» (П. Н. Краснов: От Двуглавого Орла к красному знамени, 1922); «Если ты способен быть Буддой - воплощением помощи живым существам - будь готов к тому, что, когда ты начнешь проявлять эту способность, тебя распнут как Христа» (А. Клейн: Дзен. // Пятое измерение, 2003.12. - http://klein.zen.ru/pravda/001/dzen.html), a 'тянуть за руки в разные стороны' - в строках: «В цехе друзья зажимают руки Валеры в двух тисках, распинают его как пролетарского Христа» (В. Лебедев: Вечный праздник в Москве, 2003).

${ }^{12}$ Имя божьего страстотерпца Иова в сравнениях католиков и протестантов стало символом долготерпения, т. к. именно оно помогло праведнику преодолеть все испытания и телесны е муки и вновь приобрести милость Господа: чеш. trpélivý (trpi) jako Job (ZAORÁLEK 2000: 459, СТЕПАНОвА 1985: 6); слвц. byt’ trpezlivý ako Jób (FS 1996: 13); snášet (nést) něco [trpělivee] jako Job (SČFI 1983: 142); кашуб. cerplëwi jak Job (SүснтА 1: 129); в.-луж. sćerpny kaž sputowany ['испытуемый'] Hiob (RADYSERB-WJELA 1902: 254); англ. [as] patient as Job (БЕТЕХТИНА 1995: 28); фp. être patient comme Job (SČFI 1983: 142); венг. türelmes, mint Jób (Й. А. Балажи).

${ }^{13}$ Сравнение с семантикой 'быть больным (убогим, брошенным)' редко используется в активном употреблении (OPAšı́́ 2014: 194): «Neka mi dođe u goste u Molvice, pa ću ga još masnije počastiti. A sada leži jadni Koloman u postelji kao Lazar» [Пусть он приедет ко мне в гости в Молвицу, и я его еще обильнее угощу. А сейчас лежит бедный Коломан в постели как Лазарь]. Ср. с рус. лежать как Лазарь (вроде Лазаря); бел. ляжаџь як Лазар 'о болезненном, изможденном человеке' (FEDEROWSKI 1935: 170); польск. leżé́ jak Lazarz (lazarz) - 1. 'о бедно, грязно, по-нищенски одетом и изможденно выглядящем человеке' (NKP 3: 338, ORŁoś-HoRNIK 1996: 137), 2. ‘лежать в одиночестве, всеми покинутым' (ПРФС 1: 622); кашуб. leżec jak taki lazôrz - 'о ком-л. грязном, лежащем в грязи или в лохмотьях' (TREDER 1989: 137); слвц. ležat' ako lazar 'лежать пластом (о тяжело больном, инвалиде)' (VSRS 2: 44); чеш. ležet jako Lazar (lazar) - 1. 'лежать неподвижно беспомощно; быть больным' (ZAORÁLEK 2000: 477, PAVLASOVÁ 2013: 124), 2. 'лежебока, лентяй’ (SČFI 1983: 186).

${ }^{14}$ Встречается в тексте: «Šutjeli smo 35 godina i bili strpljivi kao biblijski Job» [Мы молчали 35 лет и были терпеливы как библейский Иов] (HNK). 
Abraham $^{15}$ (OpAŠIĆ 2014: 189); biti kao Golijat ${ }^{16}$ 'быть необыкновенно сильным', [kao] David i Golijat, kao David protiv Golijata' 'как более слабый и более сильный' (OpAšIĆ 2014: 191); izdati koga kao (ko) Juda Krista ${ }^{18}$ (OpAšı́́ 2014: 193, Menac-Minalić 2003-2004: 366); izdati koga kao Juda Isusa; ${ }^{19}$ izdati koga kao Isusa Krista. ${ }^{20}$ Глагол nредаmь может иметь в текстах не только значение 'изменнически выдать кого-л., что-л.', но и 'изменить, нарушить верность кому-л., чему-л. (Родине, идее и т. п.), не сдержать слова': хорв. «Oni su šutjeli, štiteći neke, samo njima znane interese. Izdali su Hrvatsku kao Juda Isusa, kao toliko puta prije» [Они молчали, защищая какие-то только им известные интересы. Они предали Хорватию как Иуда Иисуса, как и много раз до этого] (hrWaC); рус. «Значит, можно предавать, как Иуда, Россию?» (Б. В. Савинков [В. Ропшин]: Конь вороной, 1923-1924).

Хорв. prodati kao Juda Krista (Isusa) вычленяется из текстов: Ah, zašto si me u Ženevi prodao? Kao Juda Krista si me prodao, nesretniče! (Antun Gustav Matoš $^{21}$ ); Znam ko me je prodao kao Juda Isusa, ${ }^{22}$ имеет тождества в других языках: рус. продать кого как Иуда Христа (SČFI 1983: 141); продать кого как Иуда (Огольцев 2001: 230); бел. прадаць як Юда Хрыста, прадаць Хрысma нібы Юда, ${ }^{23}$ слвц. zradit' ako Judáś Krista za 40 dinárov. ${ }^{24}$ Глагол продать (продаться) реализует семантику 'совершить предательство, измену из ко-

${ }^{15}$ Слвц. byt'starý ako Abrahám (FS 1996: 121); чеш. být starý jako Abraham (SČFI 1983: 31).

${ }^{16}$ Чеш. být jako Goliáš (SČFI 1983: 104); кашуб. chtop jak Goliôt (TREDER 1989: 137); в.-луж. mиž kaž Goliath (Івченко 1999: 194).

${ }^{17}$ Рус. как Давид и Голиаф (ССРЯ 2003: 93); как Давид с Голиафом (RUIZ-ZorILla CRUZATE 1996: 126); слвц. sú ako Dávid a Goliáš (SKLADANÁ 1999: 50); чеш. jsou jako David a Goliáś (SČFI 1983: 78); польск. wyglada jak Dawid przy Goliacie (NKP 1: 696); [sq jak] Dawid i Goliat (ORŁoŚ-HoRNIK 1996: 52); кашуб. wëzdrzec jak Dawid i Goliôt (TREDER 1989: 137); англ. [they are like] David and Goliath (ORŁOŚ-HORNIK 1996:52); wie David und Goliath aussehen (SČFI 1983:78) 1. 'о резко отличающихся друг от друга, неравноценных по качествам и внешнему виду соперниках: один очень малого роста и слабый (но умный, ловкий и хитрый), другой - чудовищно большой и сильный (но неповоротливый, тяжеловесный, медлительный и туго соображающий)'; 2. 'о людях низкого и высокого роста'; 3. 'о людях хрупкого и мощного телосложения'.

${ }^{18}$ Рус. предать кого как Иуда [Христа] (SČFI 1983: 141, ОгольцЕв 2001: 230); в.-луж. přeradźić někoho kaž Judaš (něchtó někoho přeradźi kaž Judaš) (IVČENKO-WÖLKE 2004: 125); чеш. zradit jako Jidáš [Krista] (SČFI 1983: 141); tu zrádně bratř́m učínil, jako Jidáš panu Kristovi (PAVlasová 2013: 83); слвц. zradit' niekogo ako Judáś [Krista] (SKLADANÁ 1999: 82); польск. zdradzić kogoś jak Judasz (ORŁOŚ-HORNIK 1996: 101).

${ }^{19} \mathrm{https}: / / \mathrm{hr}-\mathrm{hr}$.facebook.com/permalink.php?story... - 17.04.2011

${ }^{20} \mathrm{https}: / / \mathrm{www}$. dalje.com/hr-svijet/juda-je...isusa/3000716-05.04.2010

${ }^{21} \mathrm{http}: / / \mathrm{www} . \mathrm{moljac} . \mathrm{hr} /$ biografije/matos.htm

${ }^{22} \mathrm{https}: / /$ www.facebook.com/officialWMD/posts/384649348258980

${ }^{23}$ Вычленяется из текстов: «Пазнейшая літаратура прадоўжыць галерэю тыпаў, падобных Гаршчку і Жабіну (з апавядання таго ж Гарэцкага «Апостал»), пакажа сапраўдных пярэваратняў, людзей карыслівых і няшчырых, гатовых у імя кар'еры і самазахавання адмовіцца ад прозвішча бацькоў, прадащь іх, як некалі Юда прадаў Хрыста» (BelSoch.by 2009); «Яны хочуць, каб ён забіваў людзей. Каб прадаў Хрыста, нібы Юда, і стаў забойцам, прысягнуў, што згодны на гэта» (А. Кудласевич: Пятро, грузи жыта!, 2010).

${ }^{24}$ См. текст: «...a nakoniec nás Roman zradil ako Judáś Krista za 40 dinárov» (Východoslovenské noviny. Košice, 16.08.2001 - SNK). 
рысти': хорв. «Dr. Mita se nije kao Juda prodao za novac, on je otisao kako bi sa dalje usavrsavao i napredovao u oblasti medicine (Marković mora da vrati novac. Komentari) $)^{25}$ [Доктор Мита не как Иуда продался за деньги, он ушел, чтобы в дальнейшем совершенствоваться и развиваться в области медицины (Маркович должен вернуть деньги. Комментарии)]; рус. «- Ты мужик, а не лях и не пан. Зачем же ты, как Иуда, продал своих? Они и так богаты и знатны, а мы бедны и голы» (Г. А. Мачтет: И один в поле воин, 1886).

Предательство апостолом Иудой родоначальника христианства отражено в хорватских сравнениях odrekl se kao Juda Isusa ${ }^{26}$ и postupati kao Juda ${ }^{27}$.

Некоторые имена библейских персонажей благодаря своей христианской символике стали апеллятивами. Так, в хорватском языке «,оним“ $A \partial а м$ как апеллятив ( $а \partial a м)$ имеет значение „человек“28 》 (OPAŠIĆ 2014: 189), библейский оним Metuzalem может выступать и в качестве апеллятива: слвн. star kot metuzalem ${ }^{29}$ (FinK 2006: 239). Хорв. star kao metuzalem пейоративно обозначает очень старого человека, который отжил свой век, время которого прошло (ОрА⿱̌ı́́ 2014: 190). Нарицательным стало имя Golijat: golijat 'сильный, огромный человек, исполин, великан' ${ }^{30}$ (ОрАร̌Í́ 2014: 191). В роли апеллятива употребляется и имя библейского Лазаря: серб. лазар 'калека, бедняк, нищий, попрошайка', хорв. lazar 'калека, бедняк, больной человек, попрошайка' ${ }^{31}$ В хорватском языке апеллятив может выступать с дополнительным сдвигом значения 'прокаженный', а в жаргоне он употребляется по отношению к никчемному человеку, который «ни к селу ни к городу» (ОРАร̌ı́́ 2014: 195). Имя Иуды стало символом предателя: хорв. juda 'предатель', 32 'человек, который продастся за деньги', причем в пейоративном употреблении апеллятив может употребляться и по отношению к евреям, а словарные фиксации свидетельствуют, что в хорватских диалектах он имеет также значение ‘мелкий торговец, лавочник' (ОрАร̌Í́ 2014: 196). О переходе в апеллятив говорит написание слова с маленькой буквы: samaritanac 'милосердный (добрый) человек ${ }^{33}$ (ОРАร̌ı́́ 2014: 202). 04.2016

${ }^{25} \mathrm{http}: / /$ www.vamedia.info/index.php/home/politika/2730-markovic-mora-da-vrati-novac.07.

${ }^{26}$ sportski.net.hr/zdravko-mamic-porucio-davoru-sukeru-da-ce-ih-sve-pomesti, 20.03.2013

${ }^{27}$ «No isti ti patrioti i dalje vjeruju... da je uredno postupati kao Juda [Но те же самые патриоты продолжают верить..., что поступать как Иуда - это порядочно]» (http://www.udarno. com, 12.01.2015) (OPAŠIĆ 2014: 195).

${ }^{28}$ Ср. с рус. адам 'человек во плоти, грешник, падкий на соблазн' (ДАль 1: 13).

${ }^{29}$ Ср. с польск. устар. matuzal 'глубокий старик' (БПРС 1980: 430).

${ }^{30}$ Сp. с рус. голиаф, чеш. goliáš ‘великан' (ЧРС 1: 193); польск. goliath ‘голиаф, гигант' (БПРС 1980: 240).

${ }^{31}$ Сp. с рус. устар. лазарь 'льстивый и жалобный попрошайка, казанский нищий' (ДАль 2: 603); слвц. lazár ‘увечный или больной человек, калека, бедняк’ (KSSJ 2003: 294); польск. tazarz ‘бедняк, бедняга, горемыка' (БПРС 1980: 407); кашуб. tazôrz 'нищий’ (TREDER 1989: 137); чеш. lazar ‘больной, калека; доходяга, дохлятина' (ЧРС 1:343).

${ }^{32}$ Ту же семантику имеет слвц. judáśs (KSSJ 2003: 235), чеш. jidáśs (ЧРС 1: 266). У польск. judasz два значения: 1. 'иуда, лицемер, предатель'; 2. 'глазок (в двери)' (БПРС 1980: 295).

${ }^{33}$ Слвц. samaritán 'тот, кто бескорыстно помогает другому' (KSSJ 2003: 653). 
В диалектах Хорватии зафиксированы устойчивые сравнения, имеющие параллели в других языках Славии. Мотив чудесного зачатия и рождения Девой Марией Иисуса Христа от Духа Святого дал жизнь хорв. čist kao blažena djevica Marija 'чистая, невинная'34 (MenAC-Minalić 2003-2004: 368). $\mathrm{C}$ ее образом также связано сравнение lijepa kao djevica Marija 'очень красивая' ${ }^{35}$ (MenAC-Minalić 2003-2004: 369). Иногда однозначное в одних языках литературное сравнение имеет в диалектах другого два значения. Так, кашуб. z̈ëc jak Matuzalem (TREDER 1989: 137); слвц. žit’ [dlho] ako Metuzalem (VSRS 2: 152, RSFS 1998: 107) относятся к долгожителям, а в кайкавском диалекте хорватского языка ziveti kak Metuzalem значит: 1. 'очень долго жить'; 2. 'жить одиноко’ (Menac-Minalić 2011: 480). Интернациональный для многих языков фразеологизм наг (гол) как Адам известен лишь на юге страны: gol kao (ko) Adam (Menac-Minalić 2003-2004: 362).

Особенность разговорной речи - ярко выраженная субъективность - активизирует переход многих субстантивных лексических и фразеологических библеизмов в разряд компаративных: Juda $\rightarrow$ kao Juda ${ }^{36}$ (OpAšı́́ 2014: 195); nevjerni (nevjerovani, sumnjivi) Toma (Tome, Tomaš) $\rightarrow$ kak neverovani Toma; kaj neveruvoani Tumoaš; ka nevirni Toma 'о человеке, который никому не верит' ${ }^{37}$ (MenAC-Minalić 2003-2004: 375-376); milosrdni (dobri) Samaritanac $($ Samarijanac $) \rightarrow$ kao milosrdni samaritanac. ${ }^{38}$

Парные персонажи, почитаемые церковью как проповедники учения Христа, - апостолы Петр и Павел. В этом качестве неразделимы они и в народном сознании: серб. као Петар и Павле (Вуловић 2014: 203); хорв. устар. Petar i Pavao 'всякий, каждый' (OpAšı́́ 2014: 199); чеш. [být jako] Petr a Pavel (PavlasovÁ 2013: 114); Petr jako Pavel - 1. 'два сапога пара; один что другой’; 2. 'что так, что эдак; один черт' (MoKIENKo-WuRm 2002: 377); je to (je, to je) Petr jako Pavel; to je Pavel jako Šavel; Pavel jako šavel ${ }^{39}$ (Pavlasová 2013: 113).

${ }^{34}$ Рус. как непорочная Дева [Мария] (ССРЯ 2003: 94); слвц. byt' nepoškvrnená ako Panenka Mária (SNK).

${ }^{35}$ Слвц. pekná ako Panenka Mária (SNK).

${ }^{36}$ Рус. [как] Иуда (SČFI 1983: 141, ССРЯ 2003: 154); лемк. [як] Юда Шкарігодскый (ВАРХоЛ-Івченко 1990: 148); чеш. [jako] Jidáš (SČFI 1983: 141, MOKIENKO-WuRM 2002: 212).

${ }^{37}$ Рус. [как] Фома неверуюший (неверный - устар., книжн.) (SCFI 1983: 360); чеш. [být jako] nevěrící Tomáś (ORŁOŚ-HORNIK 1996: 262-263).

${ }^{38}$ «Oh, idi među puk iz kojeg si niko i diži ga na noge kao milosrdni samaritanac» [Ой, иди в народ, из которого ты вышел, и поднимай его на ноги как милосердный самаритянин] (hrWaC). Cp. pус. [как] добрый самаритянин (устар. добрый Самарянин, милостивый самарянин) (вычленяются из текстов); слвц. byt' ako milosrdný samaritán (FS 1996: 13); [ako] milosrdný samaritán kto; чеш. [být jako] milosrdný Samaritán (SČFI 1983: 311, ORŁoś-HoRNIK 1996: 229); польск. [być jak] miłosierny Samarytanin (ORŁoś-HoRNIK 1996: 229).

${ }^{39}$ Напомним, что иудей Савл изначально был яростным противником христианства. Но однажды по пути в Дамаск он услышал с неба голос, упрекавший его в гонениях на Иисуса с учениками. Потрясенный, Савл сменил имя, стал Павлом (паулус по-латыни - 'маленький', 'ничтожный') (БМС 2005: 571) и «сделался горячим приверженцем христианского учения, распространявшим его среди язычников от Азии до Рима и получившим поэтому прозвание „апостол язычников“» (МЛТ 2010: 349). 
Имя апостола Петра у католиков популярно и встречается как в первичных, так и вторичных устойчивых сравнениях. Непосредственно к евангельскому сюжету восходит польск. poszedtby za nim [пошел бы за ним] jak Piotr do Ogrójca ${ }^{40}$ (NKPP 2: 936). Но зафиксировано немало компаративизмов, восходящих не к Книге книг, а к народным легендам, или лишь маркированных именем этого евангельского персонажа: польск. niech je zgoda jak z Piotrym u Heroda [пусть будет согласие как с Петром у Ирода]; darzy się nieborakowi jak świętemu Piotrowi ${ }^{41}$ [везет бедняге как святому Петру] (NKPP 2: 935); trzepie sie [болтает, тараторит, треплется] jak Pietrowa mać; $;{ }^{42}$ rzuca się [горячится, громко возмущается] jak Piotrowa mać (rzucà sie jak Pietrowa mać); zazdrosny jak świętego Piotra matka (NKPP 2: 936); кашуб. zazdrosny jak Piotrowa mac (Sүснта 4:287) - 'очень завистливый'; чеш. obdařili mé z tím jako svatého Petra s podmáslím [одарили меня этим, как св. Петра пахтой] 'о не понравившемся угощении' (ZAORÁLEK 2000: 508).

В Сербии, Македонии и Хорватии устойчивы компаративизмы со сравнительной частью «как яичница святого Петра»: серб. коштати (стајати) као светог Петра кајгана (РСХКЈ 2: 629, РСХКЈ 3: 24, ТрОфимкинА 2003: 23); макед. скапо е како од Св. Петар кајгана (FINK 2006: 268); ke te koshta kako sveti Petar kajgana; go koshtalo kako Sv. Petar kajgana $;{ }^{43}$ хорв. koštati (stajati, doći) koga što (koga, što) kao svetog (svetoga, sv.) Petra kajgana (MATEŠIć 1982: 465, BABIĆ 1983-1984: 92, FinK-KovaČEVIĆ-HRNJAK 2010: 532) с семантикой 'очень дорого стоить, обходиться кому-н.' или 'платить за что-либо слишком высокую цену'. ${ }^{44}$ О происхождении фразеологизма писали не раз (BABIĆ 1983-1984, DeLIĆ 1983-1984). Приведем обширную выдержку по поводу этого компаративизма, так как его генезис для многих непонятен: Что в действительности означает «стоит как яичница святого Петра»? Идет ли здесь речь о яичнице святого Петра, которая кому-то очень дорого стоила, или, возможно, о какой-то другой яичнице, которая дорого стоила самому святому Петру? Выражение многозначное, возможно и первое, и второе толкование; для обоих имеется обоснование в притчах, легендах и литературе. Веселин Чайканович в книге «Миф и религия у сербов» высказывает мнение, что выражение заимствовано у греков с заменой имени (у греков вместо св. Петра в той же роли выступал св. Георгий). Он пишет, что в греческом

${ }^{40}$ Ogrójec (досл. tłocznia oliwek [оливковая роща]), или Гефсиманский сад - место в Иерусалиме, где Иисус молился вместе с апостолами вечером перед арестом (https://pl.wikipedia. org/wiki/Getsemani).

${ }^{41} \mathrm{~B}$ основе оборота - народная легенда о Пане Езусе и апостолах на свадьбе (NKP 2: 935).

42 Петрова мать - «образ матери св. Петра из легенд, ничем не отличающийся от образов, представленных в общепольских сказаниях» (SYснтА 4: 287). Об этимологии компаративизмов с этим компонентом см. KRZYŻANOWSKI 2: 302-305.

${ }^{43} \mathrm{http}: / /$ www.macedonians.tv/showthread.php?t=5275

${ }^{44}$ Сравнительная часть фразеологизма на формальном уровне может означать, что речь идет о генетиве (стоит как чья-либо яичница) или об акузативе (стоит как кому яичница); посессивная форма генетива наиболее частотна. 
языке существует пословица Дорога яичница святого Георгия, возникшая благодаря легенде об одном чуде, которое св. Георгий совершил в Пафлагонии. Один юноша приготовил святому Георгию яичницу... и отнес в церковь. Туда пришли четыре иноземных купца помолиться Богу, увидели яичницу и съели ее. Но святой совершил чудо, и торговцы не могли выйти из храма до тех пор, пока каждый из них не положил большую золотую монету... Когда они вышли из церкви, то сказали: «Святой Георгий, очень дорогая твоя яичница; больше никогда не будем у тебя ее покупать». Такую же легенду рассказывают греки и о Богородице. Замена имени, по мнению Чайконовича, могла возникнуть потому, что в Сербии святой Петр более известен, чем у греков, и вследствие этого данная личность «совершенно подходит для какой-то сакральной истории, которая могла бы стать основанием для возникновения нашей пословицы». Автор пишет, что это «посессивный генетив, равно как и соответствующие словоформы в греческой пословице о святом Георгии». Таким образом, речь идет об яичнице святого Петра (или Георгия), которая очень дорого обошлась кому-то.

Второе толкование берет начало в предположении, что имеется в виду какая-то яичница, которая дорого обошлась самому св. Петру. Об этом свидетельствует народное предание, зафиксированное в нескольких версиях, одну из которых обработал и представил в стихотворной форме сербский литератор Змай Йово Йованович. В его стихотворении под названием «Дорогая яичница святого Петра» говорится о том, как Иисус Христос и апостол Петр странствовали по свету, испытывая людей. А «Христос испытывал еще и своего Петра». В один из вечеров они заночевали в деревенском доме у бедной вдовы Райки, у которой было много детей. Она их радушно приняла и предложила на ужин яичницу. Христос отказался и ушел спать на соломе, предупредив святого Петра: «Смотри не съешь ее ужин, приготовленный для детей». Петр, который и без того много уже голодал, не послушал Иисуса, схватил яичницу, но та в тот же момент закаменела так, что он не смог ее есть. На следующее утро Иисус сказал Петру: «Я пойду дальше, а ты оставайся здесь. Проси милостыню, заботься о ее детях, пока я не вернусь, чтобы по моем возвращении они были здоровы». И св. Петр долго ходил от дома к дому, прося милостыню и заботясь о детях-сиротах Райки. Вернувшись, Иисус спросил его: «Все ли было в порядке? Простить тебя?» Петр, усталый и изможденный, ответил: «Все в порядке, нижайше благодарю тебя! Но яичница мне стоила дорого».

Согласно второй версии данной истории св. Петр был сильно избит хозяином дома, в котором он вместе с Христом переночевал, потому что без спроса взял и съел яичницу. Поэтому эта яичница ему дорого стоила. Иногда вместо Христа появляется фигура Бога, однако во всех версиях основным персонажем является св. Петр, который несет наказание за съеденную яичницу. В этом случае речь идет о яичнице, которую он съел и за которую ему пришлось поплатиться. На основе одной из этих легенд возникло рассматриваемое выражение, и сегодня часто употребляющееся в значениях 'очень 
дорого стоить' или 'платить за что-либо слишком высокую цену'. 45 Таким образом, сравнительная часть фразеологизма на формальном уровне может означать, что речь идет о генетиве (стоит как чья-либо яичница) или об аккузативе (во что что-либо обходится кому-либо). О наибольшей частотности посессивной формы генетива свидетельствует исследование Чайкановича. Данное сравнение византийско-греческого происхождения в сербском варианте получило новую интерпретацию: вместо св. Георгия фигурирует широко известная личность из сербских народных сказаний, легенд и пословиц св. Петр (ЧАЙКАНОВИЧ 1: 37-38).

Свою этимологию фраземы коштати (стајати) као светог Петра кајгана предлагает О. И. Трофимкина (см. Трофимкина 2003: 23-24). В хорватских диалектах этот фразеологизм имеет варианты. В местечке Докань около г. Тузла (жупания ${ }^{46}$ Дриенча, Босния) образом для сравнения вместо яичницы-болтушки является топленое масло: koštati kao svetog Petra maslo koga ‘дорого стоить' (MeNAC-MinALIĆ 2003-2004: 373), а в славонском диалекте штокавского наречия - цицвара: ${ }^{47}$ platit ko sveti Petar cicvaru 'дорого заплатит' (Menac-Minalić 2007: 115).

Для народов бывшей Югославии фразеологически значимыми оказались Христовы муки на распятии: серб. мучити се као Христос на крсту; [nатиmu] [мучиться, страдать] као Исус на крсту (Вуловић 2014: 40, 202); хорв. mučiti se kao Isukrst na raspelu (МАTоŠ 1897: 17); mučiti se kao (kak) Isus na križu (OpAŠIĆ 2014: 194, MARESIĆ 1994: 96) - 'очень мучиться, испытывать сильные страдания'; [tko] razapet je kao (ko) Isukrst 'очень сильно мучается [кто]' (Menac-Minalić 2003-2004: 365). Заметим, что другим славянским языкам этот фразеологизм не известен. Обстоятельство места (на распятии, кресте) в сравнительных оборотах может отсутствовать: серб. [напатити се] [намучиться, настрадаться] као Исус (Христ, Христос) (Вуловић 2014: 198); хорв. namučiti se kao Isus (VIDOVIĆ 2006: 66). Компаративизм не только имеет словарную «прописку», но и активно употребляется в самых разных текстах. Приведем примеры из хорватских интернет-источников: «Definitivno najneugodnije iznenađenje prvenstva je ekipa Jedinstva koja je u nekoliko prošlih prvenstava bila uvijek u samom vrhu, a sada se muči kao Isus na križu i nije dobila ni jednu ekipu iz vrha tablice» [Решительно самым неприятным сюрпризом чемпионата стала команда «Единство», которая на прошлых соревнованиях страны находилась на самой вершине, а сейчас мучится как Иисус на кресте и не победила ни одну команду, находящуюся на вершине рейтинга] (hrWaC); «Napatit ćemo se ko Isukrst na križu dok dođemo do toga, već vidim» ${ }^{48}$ [Hамучuмся как Иисус Христос на кресте, пока придем к этому, я уже это понимаю];

\footnotetext{
${ }^{45}$ http://www.dnevno.rs/info/kultura/9316/dnevnors-zasto-se-kaze-kosta-kao-svetog-petra-kaj gana

46 Жупания - административно-территориальная единица, область, округ.

${ }^{47}$ Цицвара - кулеш (жидкая кашица, похлебка из пшена или какой-л. другой крупы или муки с салом), саламата (жидкая каша из муки с маслом или салом).

${ }^{48} \mathrm{http}: / / \mathrm{www}$. forum.hr/showthread.php?p=41129956
} 
«...sad sam zvala sestru, rekla sam joj da ja jovana volim ko oci svoje ali...namučila sam se kao isukrst na križu!» ${ }^{49}$ [....ейчас я позвонила сестре. Я сказала ей, что я люблю Йована, как свои глаза, но... намучилась, как Иисус Христос на кресте]; «Eto, ima je tu karmu da je iza njega cilo vrime sta nesalomljivi otac, pa je sve završava uredno i na vrime. Mučija se ka Isukrst na križu, pa je uz oni talenat brzo uša među deset najbojih tenisači na svitu, a evo je danas i diplomira na Pravni fakultet» ${ }^{50}$ [Вот, у него была такая карма, что за ним все время стоял неприкасаемый отец, и он все заканчивал правильно и вовремя. $O H$ мучился как Иисус Христос на кресте, и с таким своим талантом он быстро попал в десятку лучших теннисистов мира, а вот сегодня еще закончил и юридический факультет].

Ветхозаветный пророк и чудотворец Илия, борец с идолопоклонством, деяния которого описаны в Третьей и Четвертой книгах царств, много раз упоминается и в Новом Завете. По Библии, он за свое подвижничество и праведность был вознесен на небо живым в огненной колеснице. В позднейших славянских православных традициях (русской, некоторых южнославянских) и в фольклоре образ Ильи-пророка связывается с громом (МЛТ 2010: 235), откуда хорв. kao sveti Ilija [galamiti, grmjeti, letjeti, voziti se]: Grmi ko da se vozi sveti Ilija po nebu (Reka). Galami ko sveti Ilija (Bihać). Vozi se ko sveti Ilija (Lipovljani). Leti ko sveti Ilija (N. Gradiška). Juri ko sveti Ilija (Petrinja) 'сильно, быстро [шуметь, кричать, возить, мчаться]' (MENAC-Minalić 2003-2004: 365); рус. [как] Илья на телеге проехал 'о громе' (Подюков 1990: 23).

Наряду с устойчивыми сравнениями-интернационализмами на основе библейских текстов и реминисценций, а также апокрифических (неканонических) текстов возникли и выражения, свойственные только одному из языков: серб. искрен као Мајка божија (Божија) 'об очень искреннем человеке' (Вуловић 2014: 41, КончАРЕвић 2015: 151, Стошић 2007: 78); хорв. bičevati koga kao Isukrst Farizejce. ${ }^{51}$ Особенно их много в диалектах. Приведем хорватские компаративизмы: proći kao (ko) Adam 'попасть в безвыходное положение, потерпеть неудачу', pravedan kao (ko) Isukrst (Opuzen - городок на юге Хорватии, в Далмации); ozbiljan kao sveti Petar na Veliki petak ['серьезный как святой Петр в Великую (Страстную) пятницу'] ${ }^{52}$ (Pleternica, Požega - города на востоке, в жупании Пожега-Славония); natući koga kao (ko) svetog Petra kajganu 'избить кого-л.' (Nova Gradiška - город на востоке, БродскоПосавская жупания); stajati (ukipiti se) kao (ko) sveti Job 'неподвижно стоять'

49 http://www.coolinarika.com/forum/coolinarika/brbljaonica/58787/?page=848

${ }^{50}$ Чакавский диалект. http://209.59.234.145/Spektar/tabid/94/articleType/ArticleView/article Id/4370/Default.aspx.

${ }^{51}$ Встречается в текстах: «- A kako da ih ožigošemo? - pitaše Mavro. - Kako? Rušiti ih sa pijedestala njihove slave! Pokazati ih svijetu kakvi su, bičevati ih kao Isukrst one Farizejce!» (E. Kumičić: Gospođa Sabina, 1883). «- А как мы их заклеймим? - спросил Мавро. - Как-как? Сбросить их с пьедестала славы! Показать миру, какие они на самом деле, бичевать их как Иисус Христос тех фарисеев!» (Э. Кумичич: Госпожа Сабина, 1883).

${ }^{52}$ Обстоятельство времени мотивировано его значимостью: это день строгого поста и воздержания в память о страстях Христовых. 
(Bjelovar); prav kao [i] sveti Petar 'абсолютно не виновен, 53 (Otok kod Sinja) (Menac-Minalić 2003-2004: 362, 365, 373, 366, 374, 381). Образование национально характерных фразеологизмов на базе текстов Книги книг - явление универсальное: подобные примеры есть в любом языке. Поскольку каждым народом Библия осваивалась самостоятельно, то у одного и того же библейского персонажа коннотаций в одном из языков может быть больше, чем в другом, или же вообще не быть. Например, в странах бывшей Югославии фразеологически не актуальны Каин и Авель.

\section{Литература}

БЕТЕХТИнА 1999 = БЕТЕХТИнА Е. Н. Фразеологизмы с библейскими именами. СанктПетербург: «Издательство Санкт-Петербургского университета», 1999.

БМС 1997 = БИРИХ А. К., МокИЕнКО В. М., СтеПАНОВА Л. И. Словарь фразеологических синонимов русского языка. Ростов-на-Дону: «Феникс», 1997.

БМС 2005 = БИРИХ А. К., МокИЕНКО В. М., СТЕПАНОВА Л. И. РУсская фразеология. Историко-этимологический словарь. Москва: «Астрель», «АСТ», 2005.

БПРС $1980=$ ГЕССен Д., СТЫПУЛА Р. Большой польско-русский словарь. Т. 1. Москва: «Русский язык», Варшава: «Ведза Повшехна», 1980.

ВАРХОЛ-ІВЧЕНКО 1990 = ВАРХОЛ Н., ІвЧЕНКО А. Фразеологічний словник лемківських говірок Східної Словаччини. Братіслава: «Словацьке педагогічне видавництво», Пряшев: «Відділ української літератури», 1990.

Вуловић 2014 = Вуловић Наташа С. Фразеолошке јединище с религијским компонентама у српском језику. Докторска дисертација. Београд, 2014.

ГРЕНАРОВА $2006=$ ГРЕНАРОВА Р. Фразеосемантическое поле «характер человека» в устойчивых сравнениях с союзом как и с антропонимами. Rossica Olomucensia 44 (2005): 733-738.

ДАль = ДАль В. И. Толковый словарь живого великорусского языка. Т. 1-4. Москва: «Прогресс», «Универс», 1994.

Івченко 1999 = Івченко А. Біблійна фразеологія верхньолужицкої мови. В кн.: Питання сорабістики. Львів: «Видавничий центр ЛНУ імені Івана Франка», 1999. 190-196.

КончАРЕВИЋ 2015 = КончАРЕВИЋ К. Уз питање о основној јединици теолингвистичких испитивања. Инвентаризација теонема и методолошки приступи њиховом проучавању). In: Српска теологија у двадесетом веку. Истражсивачки проблеми и резултати. Књ. 17. Београд: Православни богословски факултет, 2015. 144-160.

Кунин $1984=$ Кунин А. В. Англо-русский фразеологический словарь. Т. 2. Москва: «Русский язык», 1984.

КювЛИЕВА-МИШАЙКОВА 1986 = КЮВЛИЕВА-МишАЙКОВА В. Устойчивите сравнения в българския език. София: Издателство на българската академия на науките, 1986.

ЛЕПЕШАЎ = ЛЕПЕШАў І. Я. Фразеалагічны слоўнік беларускай мовы. Т. 1-2. Мінск: «Беларуская энцыклапедыя», 1993.

${ }^{53}$ Напомним, что за распространение христианского учения Петр принял мученическую смерть на распятии вниз головой. Позже католическая церковь провозгласила его первым епископом римских христиан и своим покровителем. Отсюда, видимо, и возникло данное выражение. 
МиХеЛЬСОН = МИХЕЛЬСОН М. И. Русская мысль и речь. Свое и чужое. Опыт русской фразеологии. Сборник образных слов и иносказаний. Т. 1-2. Москва: «Терра», 1994.

МЛТ $2010=$ МокиЕнко В. М., Лилич Г. А., ТРОфимкинА О. И. Толковый словарь библейских выражений и слов. Москва: «АСТ», «Астрель», 2010.

НБФР = НикОЛОВА-ГъЛъБовА Ж. Немско-български фразеологичен речник. Т. 1-2. Пловдив: «Летера», 2001.

НКРЯ = Национальный корпус русского языка. http://www.ruscorpora.ru.

Номис 1993 = Номис М. (ред.) Українські приказки, прислів'я і таке інше. Київ: «Либідь», 1993.

НУФС = Німецько-український фразеологічний словник. Т. 1-2. Київ: «Радянська школа», 1981.

Подюков 1990 = Подюков И. А. Народная фразеология в зеркале народной культуpbl. Пермь: Издательство Пермского государственного педагогического института, 1990.

ПРФС = Гюлумянц К. Польско-русский фразеологический словарь. Т. 1-2. Минск: «Экономпресс», 2004.

РАдовић 1962 = РАдовић Ј. Збирка народних изрека. Титоград: Графички завод, 1962.

РСХКЈ = Речник српскохрватскога књижевног језика. Т. 1-6. Нови Сад: «Матица српска», Загреб: «Матица хрватска», 1967-1976.

СЕЛИВеРСтовА 2013 = СЕЛИВеРстовА Е. И. [рец. на:] Harry Walter, Petra Fojtů: Schwarzes Schaf, falscher Prophet, barmherziger Samariter. Deutsch-tschechisches Wörterbuch biblischer Phraseologismen mit historisch-etymologischen Kommentaren. Greifswald, 2012. Вестник Санкт-Петербургского университета. Серия 9. Филология. Востоковедение. Журналистика. Вып. 3. Санкт-Петербург, 2013. 288-290.

ССРЯ 2003 = МокиЕнко В. М. Словарь сравнений русского языка. Санкт-Петербург: «Норинт», 2003.

СТЕПАНОВА 1985 = СТЕПАНОВА Л. И. Фразеологические единиџы с именами собственными (на материале чешского языка). Диссертация кандидата филологических наук. Ленинград, 1985.

Стошић 2007 = Стошић Љ. Библијске изреке и пословище. Београд: «Српска књижевна задруга», 2007.

ТРОФИМКИНА 2003 = ТРОФИМКИНА О. И. Экспрессивные сербские и хорватские выражения, соотносимые с текстом Библии. В кн.: Материалы XXXII международной фразеологической конференции. Вып. 27. Влияние Библии на литературные языки. Санкт-Петербург: «Филологический факультет СПбГУ», 2003. 23-27.

ФядосІк 1979 = ФядосІк А. С. (рэд.) Выслоўі. Склад, сістэматызацыя тэкстаў, уступ, артыкул і камент. М. Я. Грынблата. Мінск: «Навука і тэхніка», 1979.

ЧРС = Чешско-русский словарь / Česko-ruský slovník. T. 1-2. Москва: «Русский язык», Прага: «Государственное педагогическое издательство», 1976.

ЮрЧЕНКО-ІВчЕНКО 1993 = ЮРчеНКО О. С., ІвчЕНКО А. О. Словник стійких народних порівнянь. Харків: «Основа», 1993.

BABIĆ 1983-1984 = BABIĆ S. Jovan Jovanović Zmaj i izričaj „košta ga kao svetoga Petra kajgana”. Jezik. Časopis za kulturu hrvatskoga književnog jezika 31. Zagreb, 1983-1984. 92-93.

BüCHMANN 1864 = BüCHMANN G. Geflügelte Worte. Der Zitatenschatz des deutschen Volkes. Berlin, 1864. 
DELIĆ 1983-1984 = DELIĆ M. Postanak, značenje i stilističko obilježje izričaja: koštati kao svetog Petra kajgana. Jezik. Časopis za kulturu hrvatskoga književnog jezika 31. Zagreb, 1983-1984. 115-118.

FederowsKi 1935 = Federowski M. Lud Bialoruski na Rusi Litewskiej. T. 4. Warszawa: Towarzystwo Naukowe Warszawśkie, 1935.

FINK 2006 = FINK ARSOVSKI Ž. Hrvatsko-slavenski rječnik poredbenih frazema. Zagreb: Knjegra, 2006.

FinK-KovaČEviĆ-HrnjaK 2010 = Fink Arsovski Ž., KovaČević B., HrnjaK A. Bibliografija hrvatske frazeologije $i$ popis frazema analiziranih u znanstvenim $i$ stručnim radovima. Zagreb: Knjegra, 2010.

FS 1996 = HABOVŠTIAKOVÁ K., KROŠLÁKOVÁ E. Frazeologický slovník. Človek a príroda vo frazeológii. Bratislava: Veda, 1996.

$\mathrm{HNK}=$ Hrvatski nacionalni korpus. http://www.hnk.ffzg.hr.

$\mathrm{hrWaC}=$ Croatian web corpus. http://nlp.ffzg.hr/resources/corpora/hrwac/.

IVČENKO-WÖLKE 2004 = IVČENKO A., WÖLKE S. Hornjoserbski frazeologiski słownik Obersorbisches phraseologisches Wörterbuch-Верхнелужиикий фразеологический словарь. Budyšin/Bautzen: Ludowe nakładnistwo Domowina, 2004.

KRZYŻANOWSKI = KRZYŻANOWSKI J. Madrej głowie dość dwie stowie. T. 1-3. Warszawa: Państowy Institut Wydawniczy, 1975.

KSJP 1998 = Komputerowy stownik języka polskiego. Warszawa: PWN, 1998.

KSSJ 2003 = Krátky slovník slovenského jazyka. Bratislava: Veda, 2003.

MARESIĆ 1994 = MARESIĆ J. Iz frazeologije govora Podravskih Sesveta. Fluminensia 6 (1994): 95-98.

MATEŠIĆ 1982 = MATEŠIĆ J. Frazeološki rječnik hrvatskog ili srpskog jezika. Zagreb: Školska knjiga, 1982.

Matoš $1897=$ Matoš A. G. Odabrane pripovijetke. Zagreb, 1897. [CD-ROM.]

Menac-Menac-Minalić 1998 = Menac A., Menac-Minalić M. Frazeologija suvremenih bračkih čakavskih pjesnika. In: Riječki filološki dani 2. Rijeka: Filozofski fakultet Sveučilišta u Rijeci, 1998. 303-312.

Menac-Minalić 2003-2004 = Menac-Minalić M. Hrvatski dijalektni frazemi s antroponimom kao sastavnicom. Folia Onomastica Croatica 12-13 (2003-2004): 361-385.

Menac-Minalić 2007 = Menac-Minalić M. Iz frazeologije slavonskoga dijalekta. In: BILIĆ Anica (ur.): Šokačka rič 4. Vinkovci: Zajednica kulturno-umjetničkih djelatnosti Vukovarsko-srijemske županije, 2007. 107-124.

Menac-Minalić 2011 = Menac-Minalić M. Iz kajkavske frazeologije. Rasprave Instituta za hrvatski jezik i jezikoslovlje 37. Zagreb, 2011. 479-491.

MOKIENKO-WURM 2002 = MOKIENKO V., WuRM A. Česko-ruský frazeologický slovník. Olomouc: Vyd. Univerzita Palackého, 2002.

O. NAGY 1976 = O. NAGY Gábor: Magyar szólások és közmondások. Budapest: Gondolat, 1976.

NKPP = KRZYŻANOWSKI J. (red.) Nowa księga przysłówi wyrażeń przystowiowych polskich . T. 1-4. Warszawa: Państowy Institut Wydawniczy, 1969-1978.

OpAŠı́́ 2014 = OpAŠıć M. Biblijski onimi u hrvatskome jeziku. Folia Onomastica Croatica 23 (2014): 185-208.

ORŁOŚ-HORNIK 1996 = ORŁOŚ T. Z., HORNIK J. Czesko-polski słownik skrzydlatych słów. Kraków: Universitas, 1996.

PAVLASOVÁ 2013 = PAVLASOVÁ M. Rusko-české frazeologizmy biblického původu s křestními jmény v komparativním aspektu. Bakalárská diplomová práce. Brno, 2013. 
RADYSERB-WJELA 1902 = RADYSERB-WJELA J. Přisłowa a přistowne hrónčka a wustowa Hornjołužiskich Serbow. Budyšin: Smolerjec serbskeje knihičiščernje, 1902.

RAGUŽ 1979 = RAGUŽ D. Vlastita imena u frazeologiji. Onomastica Jugoslavica 8. Zagreb, 1979. 17-23.

RAMUŁT 1893 = RAMUŁT S. Słownik języka pomorskiego czyli kaszubskiego. Kraków: Wydawnictwo Akademii Umiejętności, 1893.

RIBAROVA 2001 = RIBAROVA S. Frazemi s biblijskim osobnim imenima u češkom i hrvatskom jeziku. Riječ. Časopis za slavensku filologiju 2001/1: 71-76.

RSFS 1998 = Dorotjaková V., ĎurČo P., Filkusová M., Petrufová M., Malíková M. O. Rusko-slovenský frazeologický slovník. Bratislava: SPN, 1998.

Ruiz-Zorilla CruZATE 1996 = Ruiz-Zorilla CruZATE М. Библеизмы в русско-каталонском сопоставлении. In: Frazeologia a religia. Tezy referatów międzynarodowego sympozjum naukowego. Opole, 4-6 września 1996 r. Opole: PRO, 1996. 125-127.

SČFI 1983 = Slownik české frazeologie a idiomatiky. Přirovnání. Praha: Academia, 1983.

SKLADANÁ 1993 = SKLADANÁ J. Frazeologický fond slovenčiny v predspisovnom obdobi. Bratislava: Veda, 1993.

SKLADANÁ 1999 = SKLADANÁ J. Slová z hlbín dávnych vekov. Bratislava: Grand Multitrade, 1999.

SKORUPKA = SKORUPKA S. Słownik frazeologiczny języka polskiego. T. 1-2. Warszawa: Wiedza Powszechna, 1967-1968.

SMIEŠKOVÁ 1974 = SMIEŠKOvÁ E. Malý frazeologický slovník. Bratislava: Slovenské pedagogické nakladatel'stvo, 1974.

$\mathrm{SNK}=$ Slovenský národný korpus. http://korpus.sk.

SYchTA = SYchTA B. Stownik gwar kaszubskich na tle kultury ludowej. T. 1-7. WrocławWarszawa-Kraków-Gdańsk: Wydawnictwo Polskiej Akademii Nauk, 1967-1976.

TREDER 1989 = TREDER J. Frazeologia kaszubska a wierzenia i zwyczaje (na tle porównawczym). Wejherowo: Muzeum Piśmiennictwa i Muzyki Kaszubsko-Pomorskiej, 1989.

VIDOVIĆ 2006 = VIDOVIĆ Bolt I. Poteškoće u prevođenju frazema (na primjerima hrvatskih i poljskih frazema) Strani jezici 35. Zagreb, 2006. 63-70.

Vöő 1999 = Vöö Gabriella: Szaván fogjuk. Erdélyi magyar szólások. Székelyudvarhely: Erdélyi Gondolat, 1999.

VSRS = Vel'ký slovensko-ruský slovnik. T. 1-6. Bratislava: Veda, 1979-1995.

WALTER 2008 = WALTER H. Wörterbuch deutscher sprichwörtlicher und phraseologischer Vergleiche. Teil 1. Hamburg: Dr. Kovač, 2008.

WDPh 2004 = Breustedt W., Getzin J., GrÄtz J., Kolsut I., Walter H. Wörterbuch deutscher Phraseologismen mit englischen und slawischen Äquivalenten. Greifswald: Ernst Moritz Arndt Universität, 2004.

WW 1982 = Wörter und Wendungen. Wörterbuch zum deutschen Sprachgebrauch. Leipzig: VEB Bibliographisches Institut, 1982.

ZAORÁLEK 2000 = ZAORÁLEK J. Lidová rčení. Praha: Academia, 2000

ZÁTURECKÝ 2005 = ZÁTURECKÝ A. P. Slovenské prislovia, porekadlá, úslovia a hádanky. Bratislava: Slovenský Tatran, 2005. 